\title{
IMAGINÁRIO E NARRATIVA
}

Marcos Vinícius Lima de Almeida

RESUMO: O presente ensaio traça uma relação entre o caráter artificial e performático de todo enunciado narrativo e as reflexões de Blanchot (2005), sobre a natureza do imaginário. Ao fim da reflexão, o texto tenta demostrar como esse lugar do imaginário é sempre um ponto de suspensão, uma dimensão ainda por vir.

Palavras-chave: imaginário, narrativa, Blanchot.

\section{UM NARRADOR IMAGINÁRIO}

O mito é o nada que é tudo

Fernando Pessoa, Ulisses

Em uma cena de 11/22/63', Jake Epping - um professor de inglês que viaja no tempo para tentar evitar o assassinato de John F. Kennedy - dá uma aula sobre a Odisseia. Os alunos estão dispersos, pouco interessados. Então Jake fecha o livro e pergunta o que eles fariam se pudessem viajar no tempo, o que eles mudariam. Alguns respondem que voltariam para matar Hitler, outros Josef Stalin ou Saddam Hussein. Uma das alunas, no entanto, ergue o braço e diz: "Eu voltaria à Grécia Antiga, para matar Homero". Assim, ela supõe, não teriam que estudar aquele livro maçante.

Há dois problemas nesses comentários. O primeiro - que incomoda 0 professor Epping - é o impulso de seus alunos: se pudessem viajar no tempo, a primeira coisa em que pensam é em matar alguém. O segundo problema, mais literário, é que Homero, pessoa física, nunca existiu. O suposto autor da Odisseia e da llíada é, ele mesmo, um ente imaginário. Tão imaginário como as aventuras de Ulisses e seus marinheiros. Seria, portanto, impossível matar Homero para evitar que a Odisseia fosse escrita. Tão impossível como matar Ulisses, o herói do livro, cujos feitos são narrados pela obra. Talvez, a única maneira de matar Homero fosse extinguir a priori toda cultura oral grega, da qual Homero é uma espécie de síntese representativa.

Pelo que se sabe, os aedos - poetas-cantores que vagavam pela Grécia Antiga, narrando mitos e lendas arcaicas - eram analfabetos: contavam tudo

${ }^{1}$ Adaptação do livro Novembro de 63, de Stephen King. Essa cena não se encontra no livro. 
de cabeça. Para garantir o processo de fixação dessas histórias, faziam uso de artifícios - a rigidez do verso, a musicalidade, os epítetos. É possível imaginar esse traçado circular e repetitivo abrindo veios na memória exemplar desses poetas. Esses veios são aquilo que chamamos de estrutura.

A poesia e a narrativa surgem ancoradas numa forma fixa porque é mais fácil para nosso espírito apreender a forma, o padrão, do que um labirinto de conteúdos variáveis. Compreendida a estrutura fixa, os poetas tinham um eixo seguro. Se acaso a memória falhasse, podiam improvisar - e talvez fosse recomendável que o fizessem -, bastava segurar o ritmo, a métrica, a sonoridade do verso. É justamente esse rumor do canto que em-canta o público. A alteração do enredo, do nome de uma personagem, ou de um detalhe de uma cena, não faz diferença - é algo acidental: uma mudança de ritmo, uma rima fora do lugar, por mínima que seja, é a perdição de um poeta.

Nessa poesia anterior à escrita, origem da própria Literatura, cada apresentar (fazer desse canto uma presença), é um cantar originário, mas também original. Originário porque remete às origens dos deuses e dos homens. Original porque a memória dos homens - embora inspirada pelas Musas -, tem a justa medida do nosso corpo: precário, lacunar, falível.

Precário, lacunar e falível, o canto do aedo se constrói a partir de um vazio. O vazio da memória. Esse vazio, que é a origem do canto, é o lugar do imaginário. Envolvidos no canto - há algo de mágico nesse processo - o próprio poeta e aqueles que o ouvem desaparecem. Esse tempo e esse espaço em que o aedo está presente vai aos poucos desaparecendo sobrepujado por um outro tempo. O tempo imaginário.

Diante de um repentista de nossa época (cujo procedimento seria o equivalente mais próximo daquilo que seria um aedo), é inevitável questionar: de que lugar nascem essas rimas? De onde elas surgem? Não são um relatório de experiências desse sujeito, tampouco são, todos esses versos, arquivos depositados na memória e acessados racionalmente. Menos ainda a expressão de ideias ou sentimentos. O próprio repentista, se questionado, poderá dizer: fiz na hora, veio do nada.

Nesse sentido, cada cantar dos aedos - o mais famoso dos aedos é aquele que conhecemos por Homero - não é um relato de feitos heroicos, já acontecidos. ${ }^{2}$ Mas é o próprio acontecimento, no sentido de uma performance.

Se cada cantar é original - acontece no próprio canto, na performance do poeta - por outro lado, não existe "o original" da Odisseia. Essa reunião de

\footnotetext{
${ }^{2}$ Aqueles leitores que se proponham a apurar a veracidade dos episódios da Odisseia e da llíada talvez saiam decepcionados. Como bem aponta Luiz-Alfredo Garcia Roza, no posfácio da edição da Cosac-Naif da Odisseia: "Homero não poderia ter sido testemunha dos combates na planície de Troia ou do retorno de Odisseu, nem poderia ter se valido do testemunho dos próprios combatentes. Os heróis da Guerra de Troia - Aquiles, Heitor, Nestor, Menelau, Agamêmnon e o próprio Odisseu - teriam vivido por volta de $1200 \mathrm{aC}$. Quatro ou cinco séculos separam Homero dos gregos e troianos protagonistas da llíada e da Odisseia. Acrescente-se a isso o fato de a escrita passar a ser usada no mundo grego somente no final do século VIII aC, e constata-se que Homero e seus heróis-guerreiros eram, pois, analfabetos. "
} 
versos que chamamos Odisseia - e que atribuímos a um suposto Homero, pessoa física - é talvez apenas uma das versões, ou reunião de múltiplas versões, daquilo que era cantado pelos aedos.

\begin{abstract}
Se nem mesmo Homero sabia cada verso da llíada e da Odisseia, já que o poeta / aedo não decorava fiel e integralmente o poema - ele fazia uso de um estoque de versos, fórmulas, estas sim decoradas, a partir dos quais recompunha o poema; ele improvisava em cima de uma estrutura decorada, de modo que a cada apresentação do poeta / aedo uma nova llíada e uma nova Odisseia eram cantadas / narradas -, então qual Odisseia foi ditada para o(s) escriba(s)? A mais próxima da original? Mas qual original? Se tanto a Odisseia como a llíada eram textos orais, compostos para serem ouvidos e não para serem lidos, como apontar o texto oral original? (GARCIA-ROZA, 2014).
\end{abstract}

Essa infidelidade inerente a Odisseia, um dos textos fundadores da Literatura Ocidental, apenas ressalta que, desde sempre, não devemos exigir da narrativa literária qualquer coisa além dela mesma. Embora seja atravessada pelo mundo que habita - e seja em última instância recebida nesse mundo empírico (por um leitor com astigmatismo, pouco paciente ou mal-humorado), - a narrativa tem suas próprias leis, seu próprio tempo.

\title{
IMAGINÁRIO E HISTÓRIA
}

Nem é só Homero, com todo o mistério ao redor de sua figura, que opera como artifício. Todo narrador é artificial (e por vezes ardiloso), porque a forma narrativa é, em si mesma, um artifício. Vejamos. Na sentença hipotética: "Ulisses ouviu o canto das sereias", a personagem fictícia - enlaçada pelo verbo no passado - provoca a impressão de que isto aconteceu de verdade, no mundo empírico. Em algum lugar, um sujeito chamado Ulisses, ouviu o canto das sereias. Essa voz manifesta no verbo é um artifício que provoca uma ambiguidade. Ao mesmo tempo que sabemos que Ulisses é uma personagem fictícia - e que não existem sereias - a frase carrega, nela mesma, uma verdade: a verdade de um acontecimento. Irrompe, aqui mesmo, no núcleo da frase, o movimento. Ulisses ouviu o canto das sereias nesse aqui mesmo, e paradoxalmente, em outro tempo. Toda essa carga de ambiguidade esfumaça os caminhos da ficção e da história, do imaginário e do mundo empírico.

Se pensarmos nas reflexões de Paul Ricoeur: uma narrativa de ficção é quase histórica (factual), pois os acontecimentos irreais que ela relata são fatos passados para a voz narrativa que se dirige ao leitor. Se assemelham, portanto, aos acontecimentos passados. Por isso a ficção se parece com a história (RICOEUR, 1997, p. 329).

Esse esfumaçamento de fronteiras é também um encantamento. Talvez por isso a aluna do professor Epping tenha colocado no mesmo plano ontológico Homero e Saddam Hussein. E com certeza é por esse motivo que 
os milhares de fãs de Sherlock Holmes remetiam cartas ao 221B Baker Street, em Londres, esperando que suas cartas chegassem ao escritório do detetive.

\section{A ORIGEM DA NARRATIVA}

As ideias esboçadas até aqui - isto é, a narrativa é um acontecimento, desde daqueles cantos performáticos dos aedos, e também no próprio núcleo do enunciado narrativo - se aproximam da concepção de narrativa de Maurice Blanchot (2005), formulada em O livro por vir. No capítulo O encontro do imaginário, ao tratar do episódio das sereias - que aparecem no Canto XII da Odisseia - o pensador francês investiga a natureza desse canto "imperfeito", "inumano" e "defeituoso".

Para Blanchot, o canto das sereias não é uma alegoria, embora represente a luta enigmática travada por toda narrativa. Se por um lado o romance nasceu também dessa luta, por outro, diferentemente da narrativa, o romance está inserido no tempo ordinário dos homens, como uma espécie de distração feliz - "o entretenimento é seu canto mais profundo". A narrativa "vai onde o romance não vai". Enquanto a narrativa rejeita tudo que a poderia aproximá-la de uma ficção - o romance faz questão se passar por tal (2005, p. 6-8). Mas caberia perguntar: que lugar é esse, que a narrativa busca alcançar, esse lugar inacessível ao romance?

Esse lugar é o lugar da origem - condição de possibilidade da própria narrativa - para onde o canto das sereias quer arrastar Ulisses, o lugar do desaparecimento. O lugar do imaginário mais profundo é ele mesmo inenarrável porque é puro silêncio, a condição fundamental de todo e qualquer canto, ruído, rumor. Aquilo mesmo que Blanchot chama a certa altura de "plenitude vazia" (2005, p.11). Toda voz, nesse lugar, desaparece porque esse lugar é pura possiblidade de voz, de toda e qualquer voz. É a origem da narrativa e concomitantemente àquilo que a narrativa persegue: a imagem possível (embora precária, como todo imagem) para sondar esse lugar, seria a imagem do círculo. Um ponto de partida é ao mesmo tempo um ponto ainda por vir. A narrativa só narra a si mesma.

Por isso Blanchot diz que a narrativa não é relato de um acontecimento, é o próprio acontecimento: "o acesso a esse acontecimento, o lugar onde ele é chamado a acontecer, acontecimento ainda por vir e cujo poder de atração permite que a narrativa possa esperar, ela também, realizar-se" (2005, p.8). Se não é um relato - e busca sempre a si mesma - a concepção de narrativa de Blanchot está longe de ser aquele processo mimético - embora desviante encontrado na tradição clássica, $A$ república de Platão e a Poética de Aristóteles, que persiste, ainda que diluída, no nosso século.

Para explicar esse movimento da narrativa, Blanchot cita o exemplo de Moby Dick. A origem do livro de Melville é o próprio encontro devastador e maravilhoso entre Achab e a baleia branca. Esse encontro arrasta o autor para a escritura; mas esse encontro só existe afinal porque que existe o livro de Melville (2005, p. 11). Não há antes. Não há depois. Não há, portanto, 
experiência. Nesse paradoxo circular, a narrativa de Melville não pertence ao que Melville viveu, à sua vida. Não se trata de criar um equivalente - dirá Blanchot - para nos fazer participar de uma visão próxima da visão do escritor. As coisas não são tão simples (2005, p. 11).

Essa visão sobre Melville especificamente - e sobre a Literatura, em geral - diferente fundamentalmente da visão de Albert Camus (2010), por exemplo, no seu famoso ensaio sobre o autor de Moby Dick. Camus começa seu texto justamente pela biografia de Melville: aos vintes e dois anos, o garoto embarcou num baleiro. Ao voltar à América, relatou aquilo que tinha visto nos mares. Como seus relatos de viagem alcançaram certo sucesso na imprensa, escreve e publica suas grandes obras que foram, evidentemente, um fracasso completo. Moby Dick, durante muito tempo, foi considerado um livro de aventura, no pior sentido do termo. Assim, "o Homero do Pacífico", como Camus (2010) o chama, terminou a vida no mais puro ostracismo. Além de dizer que Melville escreveu um único livro durante toda a sua vida, o filósofo do absurdo diz que a grande arte de Melville está em construir uma linguagem de símbolos tão poderosos que fundam uma mitologia. "Se é verdade que o escritor de talento recria a vida, ao passo que o gênio, além disso, a coroa com mitos, então não devemos duvidar que Melville é, antes de tudo, um criador de mitos" (2010, p. 29).

Embora fale em criação de mitos, a visão de Camus (2010) está próxima daquela visão clássica a respeito da Literatura: um processo mimético - uma recriação do mundo no plano da ficção. Mas o que é criar ou recriar um mundo? Pode um sujeito solitário, mergulhado em seu lugar, operar essa recriação? Depende de sua vontade?

Se lembrarmos de Ulisses, ali preso ao mastro da nau, ouvindo aquele canto das sereias - e depois, o próprio Ulisses, narrando seu feito na corte do rei Alcino - não seria esse ato de narrar uma recriação daquele canto? Poderia Ulisses recriar aquele canto do qual ouviu apenas um rumor?

Há uma passagem de Meridiano de Sangue, de Cormac McCarthy (2009), que ilumina essa questão. Não que ofereça uma resposta definitiva e conclusiva. Talvez o contrário: coloque a questão em outro plano.

Enquanto Ulisses, que escapou das sereias, tinha uma Ítaca para onde voltar e Acab via em Moby Dick um destino, a personagem do livro McCarthy vaga a esmo, é pura gratuidade, não responde a nenhum telos. Chamado simplesmente de kid, esse menino que não tem ao menos um nome é quase um espectro do que seria um homem, um homem arcaico e infantil anterior ao homem racional. Vaga pelos desertos sombrios e terras devastadas, como que mergulhado na natureza, quase animalizado, acompanhando um bando de mercenários caçadores de escalpos de nativos. A certa altura - ainda no começo da narrativa - depois de se perder no deserto, o garoto vai parar na cabana de um eremita, figura constante na obra do escritor americano. 
Buscou no canto e apanhou um velho tacho escurecido de latão, ergueu a tampa e remexeu ali dentro com o dedo. Eram os restos de lebres magras da pradaria enterrados na gordura fria e cobertos por um bolor azulado felpudo. Voltou a tampar a panela e a pôs sobre o fogo.

Não é muito mas a gente divide, disse.

Agradeço.

Perdeu seu caminho no escuro, disse o velho. Cutucou o fogo, erguendo pequenas lascas de osso no meio das cinzas.

O kid não respondeu.

$O$ velho balançou a cabeça para trás e para a frente. É duro o caminho do transgressor. Deus fez este mundo, mas não o fez bom para todos, não é?

Não parece que pensava muito em mim.

Sei, disse o velho. Mas onde chega o homem com suas ideias. Que mundo já viu de que gostasse mais?

Posso imaginar muito lugar melhor e muita vida melhor.

Consegue fazer existir? (MCCARTHY, 2009, p.25).

A resposta do garoto a questão do eremita, que será negativa, pouco importa. Também não importa a ideia de um imaginar que ergue um outro plano menos hostil e confortante a aridez da vida tal e qual. A grandeza dessa passagem não vem das respostas, mas da pergunta: "Consegue fazer existir?".

O que a reflexão de Blanchot a respeito do imaginário sugere é justamente esse ponto de suspensão, esse questionamento sobre a natureza do imaginário. E o que podemos apreender dela é que a vontade, o esforço e o empenho de um sujeito não garantem essa captura, ou esse participar do imaginário, que é um acontecer. Manter essa suspensão, essa distância que é um chamado a se perder no silêncio, mostra o imaginário como eterno estado de busca, a Literatura sempre por vir.

Ulisses foi educado para aquele encontro, Circe o instruiu, e depois Ulisses instruiu seus marinheiros. Cera e cordas, contra esses seres mágicos, que colecionavam uma pilha de corpos putrefatos ao seu redor. $\mathrm{E}$ ali, Ulisses, o racional e ardiloso, ouviu o chamado daquele lugar desde onde todo canto era possível. Mas foram as mesmas cordas, a instrução de Circe, a cera no ouvido de seus marinhos - e as ordens do próprio Ulisses a tribulação - que impediram Ulisses de mergulhar naquela origem e desaparecer por completo, como o capitão Acab no embate com a baleia, nas profundezas do mundo mágico. E assim, elas mesmas, as sereias, deixaram de existir.

\section{IMAGINARY AND NARRATIVE}

\section{Abstract}

This essay draws a link between the artificial and performative character of the whole narrative statement and the reflections of Blanchot (2005) on the 
imaginary nature. After reflection, the text tries to demonstrate how this place of imagination is always a dimension yet to come.

Keywords: imaginary, narrative, Blanchot.

\section{REFERÊNCIAS}

11.22.63. Episódio: The Truth. Criação: Bridget Carpenter. Produção: J. J. Abrams, Stephen King, Bridget Carpenter, Bryan Burk. EUA: 2016, HULU, 44$81 \mathrm{~min}$.

BLANCHOT, Maurice. I - O Canto das Sereias. I- O encontro do imaginário In: O livro por vir. Tradução: Leyla Pereno-Moisés. São Paulo: Martim Fontes, 2005.

CAMUS, Albert. Herman Melville In: A inteligência e o cadafalso. Tradução de Manuel da Costa Pinto e Cistrina Murachco. $3^{a}$ Edição. Rio de Janeiro: Record, 2010. p. 27-32.

GARCIA ROZA, Luiz-Alfredo, Posfácio In: HOMERO, Odisseia. Tradução e introdução de Christian Werner, São Paulo: Cosac Naify, 2014.

HOMERO. Odisseia. Tradução de Jaime Bruma. São Paulo: Abril, 2010.

MCCARTHY, Cormac. Meridiano de Sangue. Tradução de Cássio de Arantes Leite. Rio de Janeiro: Objetiva, 2009.

MELVILLE, Herman. Moby Dick. Tradução: Alexandre Barbosa de Souza. Cosac Naify: São Paulo, 2008.

RICOEUR, Paul. Tempo e narrativa. Tomo III. Tradução de Roberto Leal Ferreira. Campinas: Papirus, 1997. 